\title{
Why Small Business Owners Have or Do Not Have an Exit Strategy
}

By

David C. Pickard, University of South Florida

The purpose of this research is to examine the progressive and regressive factors that affect a small business owner's decision to implement an exit strategy. An exit strategy can be defined as an entrepreneur's strategic plan to sell his or her investment in a company in which he or she has controlling interest. An exit strategy gives a business owner a way to reduce or eliminate his or her stake in the business, and, if the business is successful, make a substantial profit. Exiting a business is a complicated process which includes, among other things, the evaluation, preparation, marketing, and ultimate sale of the business. Progressive fac tors push an owner to exit and regressive factors pull an owner away from exiting. The spacing between paragraphs can be altered slightly.

The substantive focus is the business owner in the lower middle market segment. This segment can be described as privately-held businesses with annual sales up to $\$ 50$ million (Census Bureau; see Exhibit 1). There are approximately 28 million businesses in this segment. Micro businesses are normally less than a million in sales with fewer than 5 employees and account for over $90 \%$ of the market. There are approximately 1.5 million businesses in the United States that are above $\$ 1$ million in sales and under $\$ 50$ million in sales (Industry expert estimate). Small businesses employ more than $50 \%$ of the population (US Small Business Administration 2017). The motivation for the research is to better understand why so many business owners in the country have no exit strategy when they are in fact operating a profitable, sustainable business. Since there are many stakeholders impacted by a small business (see Exhibit 2), this phenomenon seems worthy of an empirical study.

The research question is, "What are the progressive and regressive factors that affect a small business owner's decision whether or not to implement an exit strategy". In order to gather information pertinent to this question, the researcher designed the study method to be qualitative in order to reflect the elements involved in decision making in exiting a business. Known strengths of qualitative research are the ability to draw out rich information in a live question an answer format. Therefore, the study consists of one on one interviews with 10 randomly selected businesses owners. The business owners were found using a proprietary database of a privately-held mergers and acquisitions firm headquartered in Dallas, TX. They were divided into two groups. Group A consists of five business owners that have decided to not implement an exit strategy. Group B consists of five business owners that have decided to implement an exit strategy.

Keywords: Entrepreneurship, exit planning, mergers and acquisitions, succession planning

Copyright ${ }^{\mathcal{O}}$ 2018, David C. Pickard. This article is published under a Creative Commons BY-NC license. Permission is granted to copy and distribute this article for non-commercial purposes, in both printed and electronic formats 
Prior to data collection, the researcher received approval for the project through the institutional review board. A copy of the protocol can be seen in Exhibit 2.

Data were collected using a recording device, then transcribed and coded. The coding process included three steps. The first step was descriptive coding. Each paragraph in the interviews was described in one or two words. The second step in the process was pattern coding. Each answer to the specific theoretical questions was analyzed and placed in themes. Five basic themes emerged from the research. The final step in the coding process was theoretical.

Two separate theories emerged from the research as follows. First, the study identified what an owner's personal responsibility is to others is in his or hers decision to implement an exit strategy. Second, how is the decision to exit a business impacted by his or her happiness.

\section{Findings}

The following table identifies and applies some attributes to the two groups of business owners who were interviewed during the summer of 2018.

Table 1 presents descriptive data of the interviewees. The evidence in Table 1 suggests that these small businesses are operating in a wide variety of industries. The average revenue was $\$ 6.8$ million and $\$ 6.6$ million for the owners without and with an exit strategy. Similarly, the average age of the business owners was 64 and 59 years, respectively, suggesting that the decision of whether or not to implement an exit strategy is uncorrelated with the owner's age or size of the business (based on revenues).

Table 1: Respondent Profiles

\begin{tabular}{|c|c|c|c|c|c|c|c|c|}
\hline Group & & Type & Method & Age & Race & Gender & Education & $\begin{array}{c}\text { Revenue } \\
\text { (mil- } \\
\text { lions) }\end{array}$ \\
\hline A & 1 & Medical device & Phone & 44 & W & $\mathbf{M}$ & Bachelor's & 5 \\
\hline A & 2 & Veterinarian supply & Phone & 68 & W & $\mathbf{M}$ & Bachelor's & 21 \\
\hline A & 3 & IT & Phone & 65 & W & $\mathbf{M}$ & MBA & 3 \\
\hline A & 4 & Manufacturing & Phone & 75 & W & $\mathbf{M}$ & High School & 3 \\
\hline A & 5 & Industrial Welding & Phone & 69 & W & $\mathbf{M}$ & Bachelor's & 2 \\
\hline B & 1 & Pharmacy & Phone & 67 & W & $\mathbf{M}$ & Master's & 7 \\
\hline B & 2 & Manufacturing & $\begin{array}{l}\text { In per- } \\
\text { son }\end{array}$ & 48 & W & $\mathbf{M}$ & Some college & 3 \\
\hline B & 3 & Restaurant & $\begin{array}{l}\text { In per- } \\
\text { son }\end{array}$ & 58 & W & $\mathbf{M}$ & Bachelor's & 8 \\
\hline B & 4 & Irrigation Systems & Phone & 61 & W & M & MBA & 6 \\
\hline B & 5 & $\begin{array}{l}\text { Motorcycle Deal- } \\
\text { ership }\end{array}$ & Phone & 60 & W & $\mathbf{M}$ & Some college & 9 \\
\hline
\end{tabular}

Each interview question was formulated to correspond to the appropriate hypothesis. The interviews and answers were recorded on a device, and transcribed. Each transcription was coded after the interview. For example, for hypothesis 1.

H1: The likelihood of implementing an exit strategy $(D V)$ is a function of the owner's attitude (IV) towards an exit strategy.

The interviewees were asked the following question:

Question 1: Please describe your attitude towards implementing an exit strategy.

Table 2 presents the responses to Question 1. The evidence seems to support that more individuals in Group A (no exit strategy) were either neutral or indifferent in their attitude towards implementing an exit strategy. Conversely, individuals in Group B (exit strategy) answered with themes such as happy, positive, and excited about the idea of implementing an exit strategy. However, it is not possible to determine whether the owner's attitude toward an exit strategy drove the decision to implement the strategy, or if having implemented the strategy, these owners are now happy, positive, and excited that they have an exit strategy in place.

The second research hypothesis is:

$\mathrm{H} 2$ : The likelihood of implementing an exit strategy $(D V)$ is a function of social pressures (IV) to exit.

The question posed to the interviewees is:

Question 2: Please describe your spouses and friend's reaction if you were to tell them or if you told them you are implementing an exit strategy.

The evidence in Table 3 seems to suggest that most owners in Group A (no exit strategy) feel that their 
Table 2: Attitude towards implementing an exit strategy (Question 1):

\begin{tabular}{|l|l|l|l}
\hline Group & & \multicolumn{1}{c}{ Type } & \multicolumn{1}{c}{ Answer description } \\
\hline A & 1 & Medical device & Positive, neutral \\
\hline A & 2 & Veterinarian supply & Ambivalent, indifferent \\
\hline A & 3 & IT & Neutral, indifferent \\
\hline A & 4 & Manufacturing & Nervous, not motivated \\
\hline A & 5 & Industrial Welding & Positive, No rush or need \\
\hline B & 1 & Pharmacy & Happy, excited \\
\hline B & 2 & Manufacturing & Positive, excited \\
\hline B & 3 & Restaurant & Happy, excited \\
\hline B & 4 & Irrigation Systems & Joyful, thrilled \\
\hline B & 5 & Motorcycle Dealership & Content, Happy \\
\hline
\end{tabular}

spouses and friends would be surprised or confused if told that they are implementing an exit strategy. However, there are exceptions and most participants indicated that they would ultimately be supported with whatever decision they made. However, for the business owners in Group B (exit strategy) the evidence suggest that spouses and friends were mostly happy, excited, and supportive when they told them they had implemented an exit strategy. However, it is not possible to determine whether the direction of the effect, that is, whether an owner's social pressure or support the owner felt actually led to the implementation of the exit strategy, or whether the implementation of the strategy may have led to the support from the significant other.

Hypothesis 3 is stated below:

H3: The likelihood of implementing an exit strategy $(D V)$ is a function of the owner's perceived control (IV) over the exit decision.
The question posed to the interviewees is:

Question 3: Do you feel like you are or will be in control of your decision to implement an exit strategy?

Table 4 presents the results of question 3 .

The answers for Group A (no exit strategy) were skewed more in the direction of 'not in control', however there were two definitive answers of 'yes' to reflect they were in control. So, the results were mixed. The answers for Group B were all similar and clear, each answered that they felt completely in control of their decision to implement an exit strategy. It is possible that the likelihood of implementing an exit strategy is a function of the owner's perceived control over the exit decision.

\section{Common Themes in the Study}

The second step in the coding process was to look at patterns or other themes that may have emerged

Table 3: Reaction of spouse and friends (Question 2)

\begin{tabular}{|c|c|c|c|}
\hline Group & & Type & Answer description \\
\hline A & 1 & Medical device & Surprised, but supportive \\
\hline A & 2 & Veterinarian supply & Positive, welcoming \\
\hline$A$ & 3 & IT & Confused, but supportive \\
\hline A & 4 & Manufacturing & Supportive \\
\hline A & 5 & Industrial Welding & Surprised, but supportive \\
\hline B & 1 & Pharmacy & Supportive, in agreement \\
\hline B & 2 & Manufacturing & Excited \\
\hline B & 3 & Restaurant & Supportive \\
\hline B & 4 & Irrigation Systems & Indifferent, yet supportive \\
\hline B & 5 & Motorcycle Dealership & In agreement, supportive \\
\hline
\end{tabular}


Table 4: Sense of being in control of exit strategy (Question 3)

\begin{tabular}{|l|l|l|l}
\hline Group & & \multicolumn{1}{|c}{ Type } & \multicolumn{1}{c}{ Answer description } \\
\hline A & 1 & Medical device & Yes \\
\hline A & 2 & Veterinarian supply & Somewhat, two other partners \\
\hline A & 3 & IT & No \\
\hline A & 4 & Manufacturing & No \\
\hline A & 5 & Industrial Welding & Yes \\
\hline B & 1 & Pharmacy & Yes \\
\hline B & 2 & Manufacturing & Yes \\
\hline B & 3 & Restaurant & Yes \\
\hline B & 4 & Irrigation Systems & Yes \\
\hline B & 5 & Motorcycle Dealership & Yes \\
\hline
\end{tabular}

in the interviews. In this process, two other themes were discovered. The owner's feeling of personal responsibility to others, and the owner's personal happiness.

\section{Personal responsibility to others}

Nearly all business owners (both groups) mentioned a personal responsibility to their spouses, families, employees, customers, and suppliers. The owner's in Group A (no exit strategy) felt a need to remain in the business for others and the owner's in Group B (exit strategy) hoped their business continued on in the future and that everyone involved or effected were taken care of moving forward with an exit strategy.

\section{Personal happiness}

The majority of the owners in Group A (no exit strategy) revealed they were too happy at the moment to stop working in their business. Each seemed to enjoy their work and thought the time had not yet arrived to put an exit strategy together. Conversely, all owners in Group B (exit strategy) felt like their time had come to exit and they no longer felt happy running their business.

\section{Conclusions}

The summary of the key takeaways from the RSP. Normally, these should be under a page and should be sufficiently self-contained that a reader can jump to them and still understand them.

The evidence seems to suggest that Azjen's Theory of Planned Behavior (Azjen 1991) might be a usable model in predicting a business owner's decision to implement an exit strategy. However, more research is needed in order to suggest the possibility. It might be, but given the limitations and small sample size, such a conclusion cannot be reached.

Owners in Group A were mostly neutral or indif- ferent when asked to describe their attitude towards implementing an exit strategy. Owners in Group $B$ describes themselves as happy, or excited when asked the same question.

Owners in Group A consistently described their family and friends reaction as surprised, or confused if they were to tell them they were implementing an exit strategy. Owners in Group B consistently described their family and friends reaction as supportive and happy.

Owners in Group A answered mostly no when asked if they were in complete control of their decision to implement an exit strategy. Owners in Group B unanimously answered 'yes' when asked the same question.

Future studies with business owners might ask the question 'Describe your level of happiness with your business as a replacement for the attitude question. This is likely a better indication of an owner's motivation to implement an exit strategy.

\section{References}

Azjen, I. (1991). The theory of planned behavior, Organizational Behavior and Human Decision Processes, 50, 179-211.

\section{Review}

This article was accepted under the editorial review option. For futher details, see the descriptions at:

http://mumabusinessreview.org/peer-review-options/

\section{Where to Find Out More}

For further questions, the author can be reached at dpickard@mail.usf.edu. 


\section{Exhibit 1: Public and Private Data Sources}

\begin{tabular}{|l|l|l|l|}
\hline \multicolumn{1}{|c|}{ Source } & \multicolumn{1}{|c|}{ Name of publication or site } & \multicolumn{1}{c|}{ Title } & \multicolumn{1}{c|}{ Key message or value } \\
\hline Government & $\underline{\text { https://www.bls.gov }}$ & $\begin{array}{l}\text { US Bureau of } \\
\text { Labor Statistics }\end{array}$ & $\begin{array}{l}\text { Provides a vast amount of econom- } \\
\text { ic information and industry data }\end{array}$ \\
\hline Government & $\underline{\text { https://www.sba.gov }}$ & $\begin{array}{l}\text { Small Business } \\
\text { Administration }\end{array}$ & $\begin{array}{l}\text { Provides support and data for } \\
\text { America's small businesses }\end{array}$ \\
\hline Government & $\underline{\text { https://www.census.gov/econ/ }}$ & US Census Bureau & Business economics statistics \\
\hline $\begin{array}{l}\text { Thomson } \\
\text { Reuters }\end{array}$ & $\underline{\text { https://www.thomsonreuters.com }}$ & $\begin{array}{l}\text { Small Cap M\&A } \\
\text { review }\end{array}$ & $\begin{array}{l}\text { Summarizes M\&A activity for } \\
\text { private businesses and provides a } \\
\text { ranking of transactions and value }\end{array}$ \\
\hline MergerStat & $\underline{\text { https://www.bvresources.com }}$ & FactSet Mergerstat & $\begin{array}{l}\text { Paid subscription service that pro- } \\
\text { vides details on public and private } \\
\text { transactions }\end{array}$ \\
\hline Pitchbook & $\underline{\text { https://pitchbook.com/ }}$ & $\begin{array}{l}\text { The Pitchbook } \\
\text { Platform }\end{array}$ & $\begin{array}{l}\text { M\&A, Private Equity, \& Venture } \\
\text { Capital database }\end{array}$ \\
\hline
\end{tabular}

\section{Exhibit 2: Major Stakeholders}

\section{Stakeholders}

Business

Owners \& Stockholders

Family members

Employees

\begin{tabular}{|l|}
\hline Customers \\
\hline Suppliers \\
\hline
\end{tabular}

Buyers Professionals

Government agencies

Local communities

\section{Description}

Individual who owns a business entity in an attempt to profit from the successful operations of the company. Typically holds decision making abilities and first right to profit.

A spouse or domestic partner, child, spouse's child, daughter-in-law, son-in-law, brother, sister, mother, father, grandparents, grandchild, step-brother, step-sister, step-parents, parents-in-law, brother-in-law, sister-in-law, aunt, uncle, niece, nephew, guardian, ward.

Individuals who perform some type of service for a company in exchange for money or other form of compensation. This includes traditional and independent contractors.

A person or business that purchases a good or service from a store or business.

Any service or product-based vendor that a firm uses to complete a sale or fulfill a customer need.

Buyers of small businesses are made up of many types including high net worth individuals, competitors, international firms, large conglomerates, other small businesses, and private equity groups.

Business brokers, advisory firms, and real estate agents often play a large role in lower middle market M\&A transactions. Their roles include valuing companies, finding buyers, organizing meetings, listing the company for sale, negotiating contracts and ultimately processing the sale.

A government or state agency, often an appointed commission, is a permanent or semi-permanent organization in the machinery of government that is responsible for the oversight and administration of specific functions, such as an intelligence agency. Agencies can be established by legislation or by executive powers.

A local community is a group of interacting people sharing an environment. In human communities, intent, belief, resources, preferences, needs, risks, and a number of other conditions may be present and common, affecting the identity of the participants and their degree of cohesiveness. 


\section{Author}

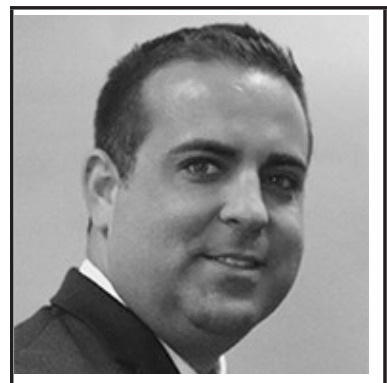

David C. Pickard is an investment banker with a focus in mergers and acquisitions. He is tasked with identifying small businesses that have a need for developing a comprehensive exit strategy, and helping select business owners prepare their company for sale. He is currently a senior managing director with Generational Equity, based in Dallas, TX. He graduated from Southwestern Assemblies of God University with a Bachelor of Science in Business Management (B.S.) in December 1999. He graduated with a Master of Business Administration (M.B.A.) from the University of South Florida (USF) in May 2007 and a Doctor of Business Administration (D.B.A) from USF in December 2018. 